\title{
Allozyme polymorphism in diploid and polyploid populations of Galium
}

\author{
Rosabelle Samuel* \\ Wilhelm Pinskert and \\ Friedrich Ehrendorfer*
}

\author{
* Institute of Botany, University of Vienna, \\ A-1030 Wien, Rennweg 14, Austria. \\ $\dagger$ Institute of General Biology, Faculty of Medicine, \\ A-1090 Wien, Währingerstr. 17, Austria.
}

Five polymorphic enzyme genes (Est-1, Est-5, Got-2, Pgi-2 and 6-Pgdh-1) were studied in Lower Austrian populations of the herbaceous, allogamous polyploid complex Galium pusillum agg. Allele frequencies in the relic $G$. austriacum$2 x$ document a high amount of genetic differentiation between the isolated, rather uniform and stenoecious populations which are separable into an older mountain and a more recent foothill series. Genetic divergence from $G$. austriacum$2 x$ is small in $G$. austriacum-4x and only somewhat greater in $G$. pumilum-8x. Allele frequencies in the $4 x$ (and $8 x$ ) suggest tetrasomic inheritance and autopolyploid behaviour in spite of nearly exclusive bivalent formation. The amount of genic variation (number of different alleles and average heterozygosity) appears uniform in diploids and polyploids. In contrast, the polyploids exhibit much increased genotypic variation as compared to the diploids. This can be linked to their more continuous, variable, euryoecious and expansive populations.

\section{INTRODUCTION}

Within the large Angiosperm genus Galium (Rubiaceae-Rubieae), the perennial herbaceous and outbreeding members of the EuropeanMediterranean sect. Leptogalium have long been the object of biosystematic studies (Ehrendorfer, 1949,1953 , and 1962). In particular, the $G$. pusillum aggregate has been shown to consist of a very polymorphic polyploid complex with several parallel series of diploids and polyploids $(x=11$ : $2 x-4 x-6 x-8 x-10 x)$ and a remarkable ecogeographical differentiation. In the foothills and lower mountains of the NE. Alps in Lower Austria, south of Vienna, this aggregate is represented by taxa exhibiting completely different variation patterns: G. austriacum- $2 x$ and $-4 x$, with a micromosaic of strongly isolated and relictual populations, and $G$. pumilum- $8 x$ with a diffuse and more or less continuous distribution of very variable and more expansive populations (Ehrendorfer 1949, 1962).

In the present study the electrophoretic analysis of enzyme proteins was used to investigate intraand interspecific variation at the gene level (cf. Gottlieb, 1977 and 1981; Hurka, 1980; Crawford, 1985). The paper concentrates on the following problems:
(1) The regional differentiation pattern of $G$. austriacum-2x.

(2) The relationships between $G$. austriacum-2, $-4 x$, and $G$. pumilum- $8 x$.

(3) The reasons for the relict or more expansive nature of these taxa.

\section{MATERIALS AND METHODS}

\section{Plant Material}

Population samples of about 30 individuals each were taken during 1988 from nine ecologically homogeneous sites in Lower Austria, south of Vienna (fig. 1): Seven diploid populations, $2 n=22$, $2 x(\mathrm{~A}-\mathrm{G})$ and one tetraploid population, $2 n=44$, $4 x(\mathrm{H})$ of Galium austriacum as well as one octoploid population of $G$. pumilum, $2 n=88,8 x$ (I). Vouchers are preserved in the herbarium of the Institute of Botany, University of Vienna (WU).

Habitats of $G$. austriacum populations are always open SW-, S- or SE-exposed slopes with shallow rendzina soils on carbonate rock (limestone or dolomite). Sites of populations A-D and F-G are loose Pinus nigra relic forests, $\mathrm{E}$ and $\mathrm{H}$ have Pinus sylvestris admixed; Sesleria caerulea subsp. varia, Polygala chamaebuxus, Calamintha 


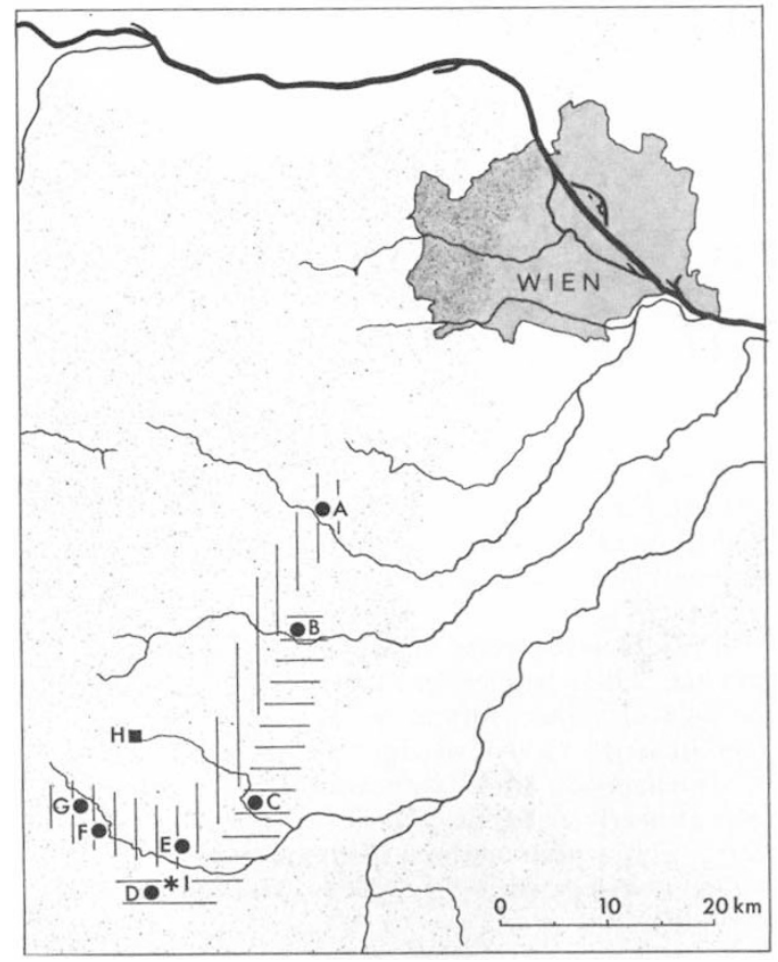

Figure 1 Sites of Galium pusillum agg. populations from the mountains south of Vienna ( $=$ Wien) in Lower Austria: G. austriacum-2x, B-C-D foothill series=horizontal hatching, A-E-F-G mountaine series = vertical hatching; G. austriacum-4x: $\mathrm{H} ; *$ G. pumilum-8x: I. Plains shown in white, mountains in grey, city boundaries of Vienna dark.

alpina, Galium lucidum, etc. are characteristic elements of the undergrowth. Sites of populations A-H are:

(A) Triesting Valley, between Pottenstein and Fahrafeld, ca. $350 \mathrm{~m}$.

(B) Piesting Valley, between Waldegg and Oed, ca. $400 \mathrm{~m}$.

(C) Sierning Valley, Mt Gösing near Sieding, ca. $500 \mathrm{~m}$.

(D) Semmering, Adlitzgraben, S. of Klamm near Schottwien, ca. $600 \mathrm{~m}$.

(E) Schwarza Valley, Mt Schneeberg: Gahns, $2.5 \mathrm{~km} \mathrm{NE}$. of Payerbach, above Obertal, $c a$. $700 \mathrm{~m}$.

(F) Schwarza Valley: Höllental, ca. $0.5 \mathrm{~km} \mathrm{~N}$. of Hirschwang, ca. $500 \mathrm{~m}$.

(G) Schwarza Valley: Höllental, ca. $0.5 \mathrm{~km} \mathrm{~S}$. of Kaiserbrunn, ca. $530 \mathrm{~m}$.

(H) Puchberg/Schneeberg, Losenheim, ca. $750 \mathrm{~m}$. Galium pumilum usually grows on brown forest soils and extends from open deciduous oak and beech forests to nutrient-poor secondary grassland. Site of population:
(I) Semmering, ca. $1 \mathrm{~km} \mathrm{NE}$. of Klamm, grassy road margins in mixed deciduous forest on schist, $c a .770 \mathrm{~m}$.

\section{Electrophoresis}

Preliminary experiments with material collected at the natural habitat and brought to the laboratory for electrophoretic analysis showed that enzyme activity is decreasing rapidly in detached leaves with time. For that reason it became necessary to establish the living plants in the garden of the Institute of Botany (HBV). For electrophoresis $40 \mathrm{mg}$ of actively growing young leaves were picked, cooled immediately on ice cubes and used for the investigations.

Leaf material was homogenized in $25 \mu \mathrm{l}$ of extraction buffer $(0 \cdot 1 \mathrm{M}$ Tris $/ \mathrm{HCl} p \mathrm{H} 7 \cdot 1$ with $3 \mathrm{mg} / \mathrm{vol}$ EDTA, $60 \mathrm{mg} / \mathrm{vol}$ PVP-40, $1 \mathrm{mg} / \mathrm{vol}$ Dithiothreitol) using 2-ml Eppendorf cups and a rotating plastic rod driven by an electric stirrer. Cooling was applied throughout homogenization. Horizontal starch gel electrophoresis was carried out according to Ayala et al. (1972). Two different buffer systems were used:

(a) bridge: $0.04 \mathrm{M}$ trisodium citrate/citric acid p 7.5

gel: $0.005 \mathrm{M}$ histidine/ $\mathrm{NaOH} p \mathrm{H} 7 \cdot 5$

run: $6 \mathrm{~h}$ at $100 \mathrm{~V} / 50 \mathrm{~mA}$

enzymes: 6-Pgdh, Pgi

(b) bridge $=$ gel: $\quad 0.087 \mathrm{M}$ Tris $/ 0.01 \mathrm{M}$ boric acid/0.0014 M EDTA $p \mathrm{H} 8.9$

run: $6 \mathrm{~h}$ at $300 \mathrm{~V} / 30 \mathrm{~mA}$

enzyme: Got

Vertical polyacrylamide gelelectrophoresis was carried out in a Hoefer Migthy Small chamber. A multiphasic buffer system (Tris/glycine, Tris/phosphate, Tris/ $\mathrm{HCl}$ ) according to Davis (1964) was used with an acrylamide concentration of 3.75 per cent in the stacking gel and 10 per cent in the resolving gel. The running time for the gel was $3 \mathrm{~h}$ at $75 \mathrm{~V} / 30 \mathrm{~mA}$. PAGE was applied for the study of esterases only.

Enzyme staining followed the standard procedures given by Harris and Hopkinson (1976) with slight modifications. Alleles were designated according to the relative mobility of the allozymes relative to the most common variant (100).

\section{RESULTS}

\section{Iso- and allozymes studied}

In a preliminary survey (data not shown) a total number of 15 enzyme systems were checked for genetic variation. Some enzyme systems (e.g., Pgm 


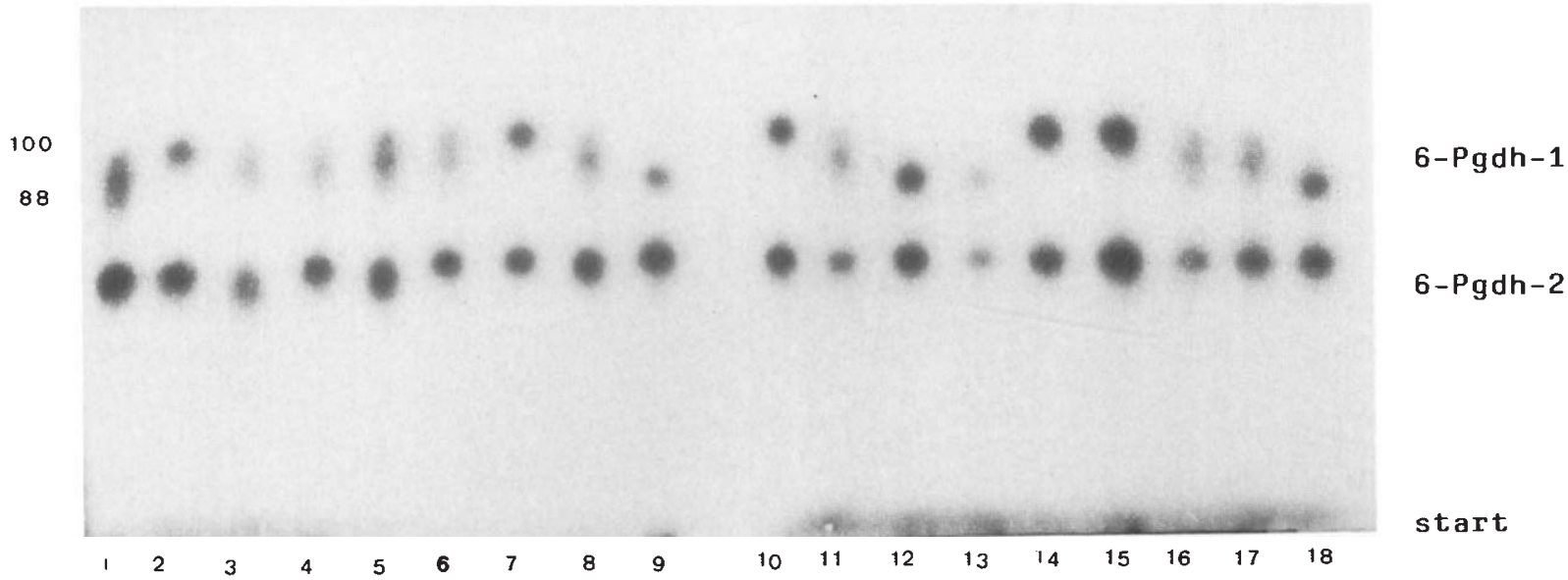

Figure 2 Zymogram for 6-Pgdh (dimeric) from 18 individuals of Galium austriacum-2x populations: 1-9 from D (Klamm) and 10-18 from B (Waldegg). 6-Pgdh-2 is monomorphic, 6- $P g d h-1$ polymorphic with two alleles (88 and 100). Individuals 9 , 12, 13 and 18 are homozygotes $88 / 88 ; 1,3,4,5,6,8,11,16$ and 17 heterozygotes $88 / 100$; and $2,7,10,14$ and 15 homozygotes $100 / 100$.

and $A d h$ ) were found to be monomorphic and thus were not analysed further. Others (e.g., $A c p h, M d h)$ were variable but difficult to interpret genetically. In Est, 6-Pgdh, Pgi and Got loci highly polymorphic isozymes with clearly interpretable banding patterns were found and hence selected for our investigation. For Est five activity zones were rec- ognized in the gel, representing five genetically independent isozymes. Three of them (Est-1, Est-2 and Est-5) were polymorphic. In Est-2 (a $\beta$ esterase according to substrate preference in vitro), however, enzyme activity appeared to be influenced by the physiological condition of the plant and changed from spring to autumn. Thus, only the

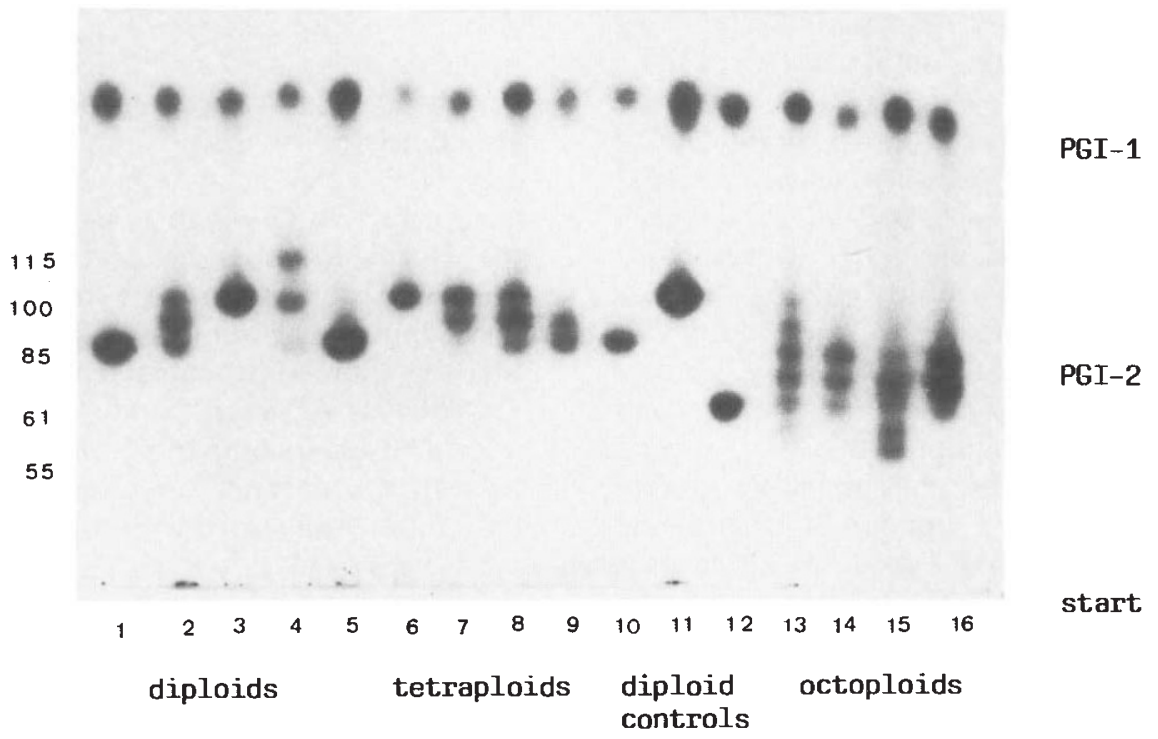

Figure 3 Zymogram for Pgi (dimeric) from Galium austriacum-2x (several populations, individuals 1-5, 10-12), G. austriacum-4x (population H: Losenheim, individuals 6-9) and G. pumilum-8x (population I: Klamm, individuals 13-16). Pgi-1 is monomorphic, Pgi-2 polymorphic with five alleles $(55,61,85,100,115)$. The following genotypes are shown: In $G$. austriacum- $2 x$ individual 12 is $61 / 61,1,5$ and 10 are $85 / 85,2$ is $85 / 100,4$ is $85 / 115,3$ and 11 are $100 / 100$; in G. austriacum-4x 9 is $85 / 85 / 85 / 100,8$ is $85 / 85 / 100 / 100,7$ is $85 / 100 / 100 / 100$ and 6 is $100 / 100 / 100 / 100$; in G. pumilum-8x, with the alleles $55,61,85$ and 100 , all four individuals are genetically different. 
Table 1 Allele frequencies (in per cent) in seven population samples of Galium austriacum-2x. $n=$ number of genes examined; $A-G=$ data from all populations pooled

\begin{tabular}{|c|c|c|c|c|c|c|c|c|c|}
\hline \multirow[b]{2}{*}{ Locus } & \multirow[b]{2}{*}{ Allele } & \multicolumn{8}{|c|}{ Population } \\
\hline & & A & B & $\mathrm{C}$ & $\mathrm{D}$ & $\mathrm{E}$ & $F$ & G & A-G \\
\hline \multirow[t]{6}{*}{ Est-1 } & 82 & - & - & - & - & - & $6 \cdot 3$ & - & $1 \cdot 0$ \\
\hline & 86 & $27 \cdot 3$ & $26 \cdot 7$ & $23 \cdot 1$ & $42 \cdot 3$ & $30 \cdot 0$ & $25 \cdot 0$ & $30 \cdot 0$ & $29 \cdot 1$ \\
\hline & 100 & $18 \cdot 2$ & $13 \cdot 3$ & $23 \cdot 1$ & - & $16 \cdot 7$ & $37 \cdot 5$ & $26 \cdot 7$ & $19 \cdot 9$ \\
\hline & 107 & $31 \cdot 8$ & $56 \cdot 7$ & $46 \cdot 2$ & $57 \cdot 7$ & $23 \cdot 3$ & $31 \cdot 3$ & $36 \cdot 7$ & $40 \cdot 3$ \\
\hline & 120 & $22 \cdot 7$ & $3 \cdot 3$ & $7 \cdot 7$ & - & $30 \cdot 0$ & - & $6 \cdot 7$ & $9 \cdot 7$ \\
\hline & $n$ & 22 & 30 & 26 & 26 & 30 & 32 & 30 & 196 \\
\hline \multirow[t]{3}{*}{ Est -5} & 90 & $45 \cdot 8$ & $56 \cdot 7$ & $26 \cdot 9$ & $29 \cdot 2$ & $60 \cdot 7$ & $85 \cdot 3$ & $40 \cdot 0$ & $51 \cdot 0$ \\
\hline & 100 & $54 \cdot 2$ & $43 \cdot 3$ & $73 \cdot 1$ & $70 \cdot 8$ & $39 \cdot 3$ & $14 \cdot 7$ & $60 \cdot 0$ & $49 \cdot 0$ \\
\hline & $n$ & 24 & 30 & 26 & 24 & 28 & 34 & 30 & 196 \\
\hline \multirow[t]{3}{*}{ Got-2 } & 72 & $10 \cdot 0$ & - & $19 \cdot 2$ & $13 \cdot 3$ & - & $20 \cdot 8$ & $10 \cdot 7$ & $10 \cdot 1$ \\
\hline & 100 & $90 \cdot 0$ & $100 \cdot 0$ & $80 \cdot 8$ & $86 \cdot 7$ & $100 \cdot 0$ & $79 \cdot 2$ & $89 \cdot 3$ & $89 \cdot 9$ \\
\hline & $n$ & 30 & 26 & 26 & 30 & 34 & 24 & 28 & 198 \\
\hline \multirow[t]{5}{*}{ Pgi-2 } & 61 & $7 \cdot 1$ & $9 \cdot 4$ & $3 \cdot 6$ & $2 \cdot 6$ & $21 \cdot 9$ & $13 \cdot 3$ & $3 \cdot 6$ & $8 \cdot 8$ \\
\hline & 85 & $21 \cdot 4$ & $43 \cdot 8$ & $60 \cdot 7$ & $36 \cdot 8$ & $25 \cdot 0$ & $33 \cdot 3$ & $35 \cdot 7$ & $36 \cdot 6$ \\
\hline & 100 & $71 \cdot 4$ & $31 \cdot 3$ & $32 \cdot 1$ & $60 \cdot 5$ & $53 \cdot 1$ & $53 \cdot 3$ & $60 \cdot 7$ & $51 \cdot 8$ \\
\hline & 115 & - & $15 \cdot 6$ & $3 \cdot 6$ & - & - & - & - & $2 \cdot 8$ \\
\hline & $n$ & 28 & 32 & 28 & 38 & 32 & 30 & 28 & 216 \\
\hline \multirow[t]{3}{*}{ 6-Pgdh-1 } & 88 & - & $56 \cdot 3$ & $10 \cdot 0$ & $39 \cdot 5$ & $18 \cdot 8$ & 21.9 & - & $22 \cdot 3$ \\
\hline & 100 & $100 \cdot 0$ & $43 \cdot 7$ & $90 \cdot 0$ & $60 \cdot 5$ & $81 \cdot 2$ & $78 \cdot 1$ & $100 \cdot 0$ & $77 \cdot 7$ \\
\hline & $n$ & 28 & 32 & 30 & 38 & 32 & 32 & 28 & 220 \\
\hline
\end{tabular}

two $\alpha$-esterases Est-1 (alleles 82, 86, 100, 107 and 120) and Est-5 (alleles 90 and 100) were analysed in our study.

In each of the 6-Pgdh, Pgi and Got enzyme systems, two isozymes were obtained, one of them polymorphic (6-Pgdh-1, Pgi-2, Got-2), the other monomorphic (6-Pgdh-2, Pgi-1, Got-1). A zymogram for 6-Pgdh in G. austriacum-2x (fig. 2) shows the three genotypes in 6-Pgdh-1 (alleles 88 and 100). Data for Got-2 are closely comparable. In contrast, for the polymorphic Pgi-2 (fig. 3, tables 1 and 5), six different alleles have been found (55, $61,75,85,100$ and 115). Consequently, genetic interpretation of Pgi-2 zymograms is more complex in $2 x$ and $4 x$, and quite difficult in $8 x$ taxa. According to the banding pattern in the heterozygotes, Est-1 and Est-5 appear as monomeric enzymes. In 6-Pgdh-1, Got-2 and Pgi-2 the three bands of activity found in the heterozygotes suggest a dimeric structure of the enzymes.

\section{Allele frequencies and ecogeographical differentiation of diploid populations}

The allele frequencies of the five polymorphic genes in the seven $G$. austriacum- $2 x$ populations are shown in table 1 . A $\chi^{2}$-test for heterogeneity (table 2) reveals ecogeographical variation between populations. Significant differences are found for all five genes. This result indicates that these diploid populations do not belong to one large panmictic assembly but instead are partially isolated.

Observed and expected heterozygosity values are compared in table 3. At two loci (Est-5 and 6-Pgdh-1) a significant deficiency of heterozygotes is observed. In Got-2 and Pgi-2 the deviation from the Hardy-Weinberg expectation points to the same direction, although here the differences are not significant. From the pooled data of the five loci the inbreeding coefficient was calculated as $F_{\mathrm{ST}}=0 \cdot 171$. Because $G$. austriacum and its relatives are self-incompatible (Ehrendorfer, unpublished), the decrease in observed heterozygosity has to be ascribed to the fragmented population

Table 2 Test for heterogeneity of allele frequencies between the Galium austricacum- $2 x$ populations. $\mathrm{df}=$ degrees of freedom; $P=$ probability

\begin{tabular}{llrl}
\hline Locus & $\chi^{2}$ & df & $P$ \\
\hline Est -1 & $45 \cdot 7$ & 18 & $<0.001$ \\
Est -5 & $29 \cdot 8$ & 6 & $<0.001$ \\
Got -2 & $12 \cdot 6$ & 6 & $<0.05$ \\
Pgi-2 & $28 \cdot 8$ & 12 & $<0.01$ \\
6-Pgdh-1 & 46.7 & 6 & $<0.001$ \\
\hline
\end{tabular}


Table 3 Observed and expected heterozygosity per locus $\left(H_{\mathrm{L}}\right)$ and average heterozygosity $(\bar{H})$ for the five polymorphic genes in Galium austriacum-2x. $N=$ number of genotypes tested; ***,*** = significant at the $0 \cdot 05,0 \cdot 01,0 \cdot 001$ level; $\mathrm{df}=1$ in all tests.

\begin{tabular}{|c|c|c|c|c|c|}
\hline \multirow[b]{2}{*}{ Locus } & \multicolumn{2}{|l|}{$H_{\mathrm{L}}$} & \multirow[b]{2}{*}{$N$} & \multirow[b]{2}{*}{$\chi^{2}$} & \\
\hline & Obs. & Exp. & & & \\
\hline Est-1 & 0.735 & 0.704 & 98 & 0.44 & ns \\
\hline Est-5 & $0 \cdot 265$ & 0.500 & 98 & $21 \cdot 62$ & $* * *$ \\
\hline Got-2 & $0 \cdot 141$ & $0 \cdot 182$ & 99 & 1.09 & ns \\
\hline Pgi-2 & 0.537 & 0.589 & 108 & $1 \cdot 20$ & ns \\
\hline 6-Pgdh-1 & 0.246 & $0 \cdot 347$ & 110 & $4 \cdot 94$ & $*$ \\
\hline$\vec{H}$ & $0 \cdot 385$ & 0.464 & 513 & $13 \cdot 23$ & $* * *$ \\
\hline
\end{tabular}

structure and not to autogamy. Gene flow between the subpopulations appears to be inhibited by geographical barriers. But even between populations located in the same valley (e.g., E-F-G) and over a distance of only ca. $10 \mathrm{~km}$, significant local differences in the allele frequencies can be observed at the five polymorphic loci (table 2).
Table 4 Genetic identity values (Nei's $I$ ) between the Galium austriacum $-2 x$ populations $\mathrm{A}-\mathrm{G}$, calculated from the allele frequencies at the five polymorphic loci

\begin{tabular}{|c|c|c|c|c|c|c|}
\hline & B & $\mathrm{C}$ & D & $\mathrm{E}$ & $\mathrm{F}$ & G \\
\hline A & 0.8297 & 0.9236 & 0.9047 & 0.9671 & 0.9048 & 0.9879 \\
\hline B & & 0.8680 & 0.9385 & 0.8950 & 0.8739 & 0.8497 \\
\hline C & & & 0.9258 & 0.8903 & 0.8435 & 0.9625 \\
\hline D & & & & 0.8912 & 0.8305 & 0.9222 \\
\hline $\mathrm{E}$ & & & & & 0.9349 & 0.9488 \\
\hline $\mathrm{F}$ & & & & & & 0.9055 \\
\hline
\end{tabular}

From the allele frequencies in G. austriacum-2x populations the coefficient of genetic identity (I) was calculated according to Nei (1972). An identity matrix is given in table 4, based on the data of the five polymorphic loci. From the identity matrix a dendogram was constructed (fig. 4) by means of the UPGMA-method (Sneath and Sokal, 1973). The dendogram clearly shows that the population samples fall into two distinct clusters. This clustering is consistent with the geographic distribution and ecological differences, and corresponds to a

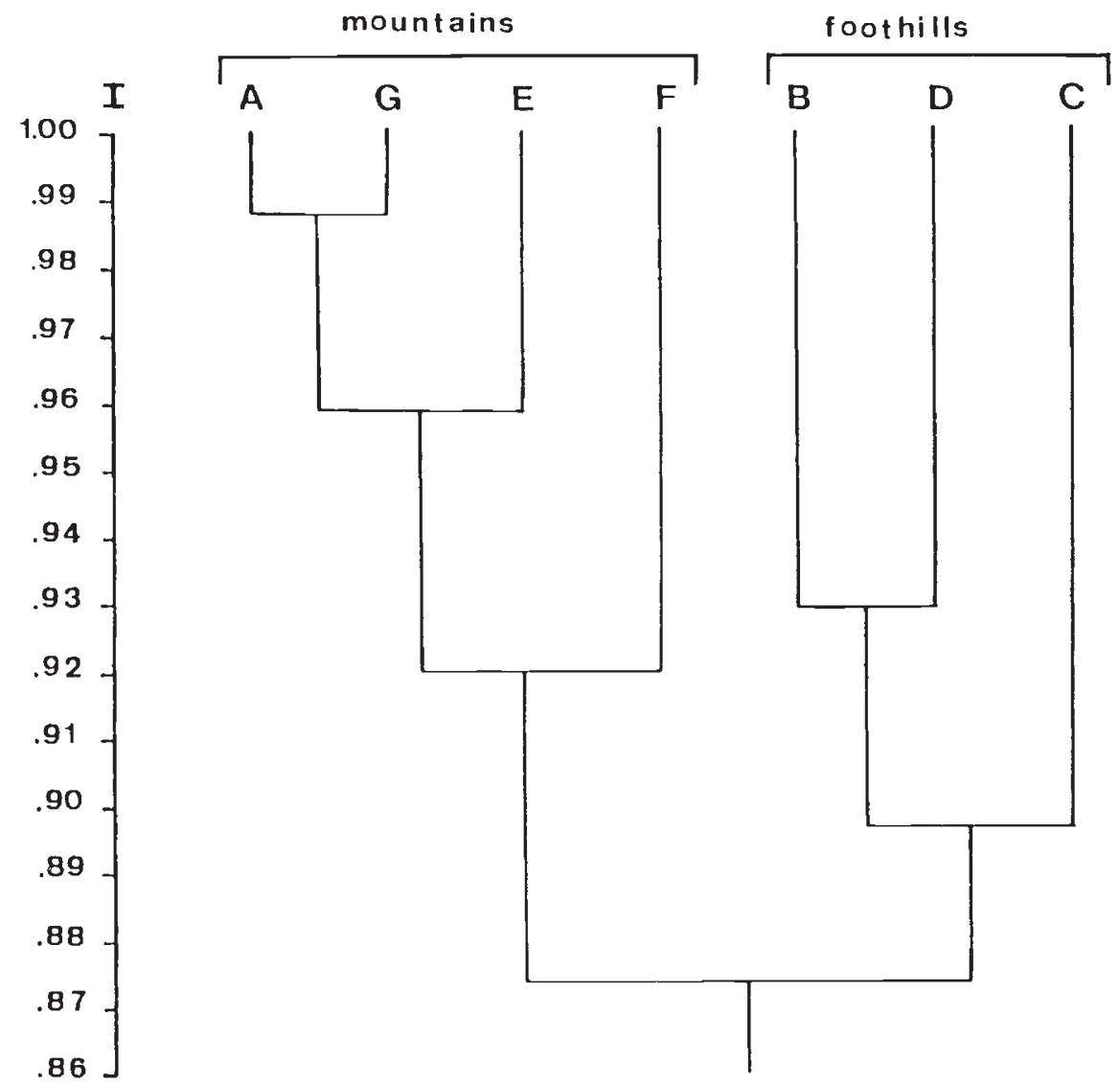

Figure 4 UPGMA dendrogram of Galium austriacum-2x populations A-G calculated from the identity matrix ( $c f$. table 4 ). The mountain series A-E-F-G stands apart from the foothill series B-C-D. 
foothill series including the populations B-C-D and a mountain series with the populations A-EF-G. At the level of allele frequencies the differences between the two clusters proved statistically significant at four of the five polymorphic loci (Est-1: $\chi^{2}=15 \cdot 7, \mathrm{df}=3, P<0 \cdot 01:$ Est $-3: \chi^{2}=8 \cdot 14$, $\mathrm{df}=1, P<0 \cdot 01 ;$ Got-2: ns; Pgi-2: $\chi^{2}=17 \cdot 1, \mathrm{df}=3$, $P<0.001 ; 6$ Pgdh-1: $\chi^{2}=21 \cdot 2$, df $=3, P<0 \cdot 001$ ).

\section{Genic variation and relationships of diploid and polyploid populations}

In order to assess the relationships of $G$. austriacum- $2 x$ within the $G$. pusillum aggregate, samples of a $G$. austriacum- $4 x(\mathrm{H})$ and $G$. pumilum-8x (I) were analysed in a comparable manner as for Pgi and Est-1.

An example of the observed electrophoretic phenotypes for $P g i$ is given in fig. 3. The Pgi-1 isozyme is constantly monomorphic, and both diploids and polyploids, appear homozygous for the same electrophoretic allele. On the other hand, $P g i-2$ is polymorphic with multiple alleles in diploids and polyploids (tables 1 and 5). Some alleles, e.g., 85 and 100 , are shared by all three taxa indicating an ancient polymorphism already present in the common ancestor. A few alleles may be more limited: 115 so far has been found only in G. austriacum- $2 x$ and $4 x, 61$ only in G. austriacum- $2 x, 75$ only in G. austriacum- $4 x$, and 55 only in $G$. pumilum-8x.

The interpretation of the electrophoretic phenotypes in Pgi-2 (fig. 3 ) is readily achieved with the $2 x$ and $4 x G$. austriacum populations. The $2 x$ show the characteristic banding pattern of a dimeric enzyme in the heterozygotes. As expected with random association of the peptide subunits, the band representing the heterodimer is about twice as intense as each of the two homodimers. In the $4 x$, where each gene is present in four copies, three different heterozygotes are observed: the $2 / 2$ heterozygotes with two copies of each allele and two different types of $3 / 1$ heterozygotes. The electrophoretic phenotype of the $2 / 2$ heterozygotes is the same as in heterozygous diploids. In the $3 / 1$ heterozygotes, however, the ratio of the three bands is $9: 6: 1:$, and since the homodimer from the rare allele contributes only $6 \cdot 25$ per cent of the total enzyme activity, its staining is very faint. According to what can be estimated from the direct comparison in the gel, the amount of enzyme produced in $2 x$ and $4 x$ is about the same. That means, that all four copies of the gene in $4 x$ contribute to the phenotype, but each with a reduced activity as compared to the $2 x$.
In G. pumilum- $8 x$ the $P g i-2$ banding patterns become even more complicated due to the fact that several different alleles can occur in a single genotype, and that heterodimers are formed between the different polypeptides. In fig. 3 two of the octoploids shown possess two alleles, yet the ratio of the two alleles could be either $4 / 4$ or $5 / 3$. The other two phenotypes apparently are produced by four different alleles, but it seems impossible to determine the copy numbers exactly. The expected staining intensity of a homodimer from a particular allele is 1.6 per cent of the total. This means that the band is too faint to be detected in the gel.

Table 5 Number of individuals observed for the different genotypes at Est-1 and Pgi-2 in G. austriacum-2x and $-4 x$. $\mathrm{G}=$ number of different genotypes, $\mathrm{N}=$ number of individuals

\begin{tabular}{|c|c|c|c|c|}
\hline \multirow[b]{3}{*}{ Locus } & \multicolumn{4}{|c|}{ Galium austriacum } \\
\hline & \multicolumn{2}{|l|}{$2 x$} & \multicolumn{2}{|l|}{$4 x$} \\
\hline & Genotype & $\mathbf{N}$ & Genotype & $\mathbf{N}$ \\
\hline \multirow[t]{22}{*}{ Est-1 } & $86 / 86$ & 6 & - & - \\
\hline & $100 / 100$ & 6 & - & 一 \\
\hline & $107 / 107$ & 14 & - & - \\
\hline & $82 / 86$ & 1 & - & - \\
\hline & $82 / 100$ & 1 & - & 一 \\
\hline & $86 / 100$ & 9 & $86 / 86 / 100 / 100$ & 2 \\
\hline & $86 / 107$ & 27 & - & - \\
\hline & $86 / 120$ & 8 & - & 一 \\
\hline & $100 / 107$ & 15 & - & 一 \\
\hline & $100 / 120$ & 2 & - & 一 \\
\hline & $107 / 120$ & 9 & - & - \\
\hline & - & - & $86 / 86 / 86 / 100$ & 1 \\
\hline & - & - & $86 / 100 / 100 / 100$ & 1 \\
\hline & - & - & $86 / 86 / 86 / 107$ & 1 \\
\hline & - & - & $80 / 80 / 100 / 107$ & 1 \\
\hline & - & - & $80 / 80 / 107 / 120$ & 1 \\
\hline & - & - & $80 / 107 / 107 / 120$ & 1 \\
\hline & - & - & $86 / 86 / 100 / 107$ & 1 \\
\hline & - & - & $86 / 100 / 107 / 107$ & 1 \\
\hline & - & - & $86 / 107 / 107 / 120$ & 1 \\
\hline & - & - & $100 / 107 / 120 / 120$ & 1 \\
\hline & $G=11$ & 98 & $G=11$ & 12 \\
\hline \multirow[t]{13}{*}{$P g i-2$} & $61 / 61$ & 2 & - & - \\
\hline & $85 / 85$ & 15 & 一 & 一 \\
\hline & $100 / 100$ & 33 & $100 / 100 / 100 / 100$ & 1 \\
\hline & $61 / 85$ & 5 & - & - \\
\hline & $61 / 100$ & 9 & - & - \\
\hline & $85 / 100$ & 38 & $85 / 85 / 100 / 100$ & 1 \\
\hline & $85 / 115$ & 6 & $85 / 85 / 115 / 115$ & 1 \\
\hline & - & - & $75 / 75 / 75 / 100$ & 1 \\
\hline & - & - & $75 / 100 / 100 / 100$ & 1 \\
\hline & - & - & $85 / 85 / 85 / 100$ & 1 \\
\hline & - & - & $85 / 100 / 100 / 100$ & 4 \\
\hline & - & - & $100 / 100 / 100 / 115$ & 2 \\
\hline & $\mathrm{G}=7$ & 108 & $\mathrm{G}=8$ & 12 \\
\hline
\end{tabular}


Table 6 Allele frequencies (in per cent) for Est-1 and Pgi-2 in populations of Galium austriacum$2 x$ (mountain series: A, E, F, G and foothill series: B, C, D) and $-4 x(H) . n=$ number of genes examined

\begin{tabular}{|c|c|c|c|c|}
\hline \multirow[b]{2}{*}{ Locus } & \multirow[b]{2}{*}{ Allele } & \multicolumn{2}{|c|}{ Galium austriacum- $2 x$} & \multirow{2}{*}{$\begin{array}{l}\text { Galium } \\
\text { austriacum- } 4 x \\
(H)\end{array}$} \\
\hline & & $\begin{array}{l}\text { Mountains } \\
(\mathrm{A}, \mathrm{E}, \mathrm{F}, \mathrm{G})\end{array}$ & $\begin{array}{l}\text { Foothills } \\
\text { (B, C, D) }\end{array}$ & \\
\hline \multirow[t]{7}{*}{ Est-1 } & 80 & - & - & $10 \cdot 4$ \\
\hline & 82 & $1 \cdot 8$ & - & - \\
\hline & 86 & $28 \cdot 1$ & $30 \cdot 5$ & $31 \cdot 3$ \\
\hline & 100 & $25 \cdot 4$ & $12 \cdot 2$ & $25 \cdot 0$ \\
\hline & 107 & $30 \cdot 7$ & $53 \cdot 7$ & $22 \cdot 9$ \\
\hline & 120 & $14 \cdot 0$ & $3 \cdot 7$ & $10 \cdot 4$ \\
\hline & $n$ & 114 & 82 & 48 \\
\hline \multirow[t]{6}{*}{$P g i-2$} & 61 & $11 \cdot 9$ & $5 \cdot 1$ & - \\
\hline & 75 & - & - & $8 \cdot 3$ \\
\hline & 85 & $28 \cdot 8$ & $45 \cdot 9$ & $22 \cdot 9$ \\
\hline & 100 & $59 \cdot 3$ & $42 \cdot 9$ & $60 \cdot 4$ \\
\hline & 115 & - & $6 \cdot 1$ & $8 \cdot 3$ \\
\hline & $n$ & 118 & 98 & 48 \\
\hline
\end{tabular}

Because of these difficulties with reliable genotype determinations, we had to exclude the octoploids from our more detailed comparisons.

In table 5 the genotypes at Est-1 and Pgi-2 found in $G$. austriacum $-2 x$ and $-4 x$ are compared, and corresponding allele frequencies are given in table 6. Considering the amount of genic variation, no striking difference is observed between $2 x$ and $4 x$. The number of different alleles is exactly the same at both genes. Two alleles (Est $1^{82}$ and Pgi$2^{61}$ ) were found only in the $2 x$, two others (Est $-1^{80}$ and $\left.P g i-2^{75}\right)$ apparently are characteristic for $4 x$. Average heterozygosity calculated for the two loci is almost the same $(0.647$ vs. $0 \cdot 667)$. In the $4 x$ no fixed heterozygosity is apparent: inheritance follows the tetrasomic pattern of autopolyploids.

A clear difference, however, is found with respect to genotypic variation. In G. austriacum- $2 x$ 11 different genotypes among 98 individuals were found at the Est-1 gene, 7 out of 108 at Pgi-2. The corresponding numbers for $4 x$ are 11 out of 12 for Est-1 and 8 out of 12 for Pgi-2. This means that almost every $4 x$ individual carries its particular genotype. The main genetic difference between $2 x$ and $4 x$ is the much higher genotypic variation in the tetraploids due to their higher number of possible combinations, even if the genetic raw material in the form of different alleles is very similar in both.

In table 7 genetic identity $I_{\mathrm{N}}(\mathrm{Nei}, 1972)$ and genotypic identity $I_{\mathrm{H}}$ (Hedrick, 1971) were calculated between the two series of $G$. austriacum- $2 x$ populations and the $G$. austriacum- $4 x$ population (H). Surprisingly, at both loci $I_{\mathrm{N}}$ was highest
Table 7 Genetic identity $I_{N}$, calculated from allele frequencies (Nei, 1972), and genotypic identity $I_{\mathrm{H}}$, calculated from genotype frequencies (Hedrick, 1971), between populations of $G$. austriacum. The $2 x$-mountain series ( $2 \mathrm{x}-\mathrm{m})$, the $2 x$-foothill series $(2 x$-f $)$, and one $4 x$-population are compared

\begin{tabular}{lllll}
\hline Locus & & $2 x-\mathrm{m} / 2 x-\mathrm{f}$ & $2 x-\mathrm{m} / 4 x$ & $2 x-\mathrm{f} / 4 x$ \\
\hline Est -1 & $I_{\mathrm{N}}$ & 0.8957 & 0.9613 & 0.8279 \\
& $I_{\mathrm{H}}$ & 0.6559 & 0.2340 & 0.0000 \\
\multirow{2}{*}{ ggi-2 } & $I_{\mathrm{N}}$ & 0.9257 & 0.9643 & 0.8883 \\
& $I_{\mathrm{H}}$ & 0.8849 & 0.2575 & 0.2800 \\
\hline
\end{tabular}

between $4 x$ and the mountain series of $2 x$. This is remarkable because the $4 x$ sample was taken from the same valley system as the $2 x$ population $C$, a member of the foothill series.

At the genotypic level the highest $I_{\mathrm{H}}$ similarity is observed between the $2 x$ foothill and the $2 x$ mountain series. The $4 x$ population is genotypically differentiated from both $2 x$ clusters, but still closer to the mountain series. In one case (Est-1 in the comparison with the $2 x$ foothill series) no common genotype was found at all. Thus, G. austriacum- $4 x$ differs from $G$. austriacum- $2 x$ not only by its higher amount of genotypic variation within the population, but also by genotypic divergence.

\section{DISCUSSION}

Deviations of genotype frequencies for allozymes from Hardy-Weinberg expectations $\left(F_{\mathrm{ST}}\right)$ are clearly correlated to the reproductive system, i.e., 
they are lower in allogamous and higher in autogamous populations (Levin, 1978; Loveless and Hamrick, 1984; Hamrick, 1987). Our data on Galium austriacum- $2 x(F=0 \cdot 171)$ are in line with pollination experiments demonstrating self-incompatibility and obligatory allogamy (Ehrendorfer, unpublished), and comparable with $F$ values for outbreeding (but not panmictic) species, e.g., of Lupinus (Babbel and Selander, 1974), Stephanomeria (Gottlieb, 1975), and Phlox (Levin, 1978). In contrast, for taxa of Relbunium, a genus related to Galium, allozyme data have given clear evidence for autogamy (Cavalli-Molina et al., 1989).

The $F_{\mathrm{ST}}$ coefficient (being relatively high for an allogamous group) and the advanced genetic differentiation of the $G$. austriacum- $2 x$ populations clearly demonstrate strongly limited gene flow and lack of panmixis. As in Coreopsis cyclocarpa and C. grandiflora (Crawford and Bayer, 1981; Crawford and Smith, 1984), and in Phlox drummondii (Schwaegerle et al., 1986), this can be linked to the relative inefficiency of long-distance pollen and seed transfer of G. austriacum. Furthermore, one has to consider the strongly isolated nature of its habitats: open and rocky Pinus nigra forests on steep limestone or dolomite slopes. Such habitats with their more ancient and relic vegetation appear as islands among the otherwise dominating postglacial climax formations of deciduous forests or secondary communities under human influence on deeper and better soils. This ecological isolation is reinforced by the strongly dissected orographic situation of the area. Thus, the populations of $G$. austriacum-2x studied, correspond to the "stepping-stone" pattern of gene flow as described by Hamrick (1987), comparable to species of Quercus subg. Erythrobalanus (Manos and Fairbrothers, 1987) or Hawaiian Islands Tetramolopodium (Lowrey and Crawford, 1985).

Many recent papers have shown the significance of iso- and allozyme data for elucidating the phylogentic links between related diploid and polyploid taxa of vascular plants (Roose and Gottlieb, 1976; Werth et al., 1985; Hurka et al., 1989; Sanchez de Hoz and Fominaya, 1989).

The close relationship between the members of the polyploid complex G. pusillum agg. is documented by their similar iso- and allozymes (table 5, fig. 4), e.g., with the monomorphic Pgi-1 and the alleles for Pgi-2 $2^{85}$ and Pgi-2 ${ }^{100}$ occurring in $G$. austriacum- $2 x,-4 x$ and $G$. pumilum- $8 x$. Possible qualitative genetic differences among these taxa in respect to iso- and allozymes need confirmation.
But in respect to allele frequencies (table 7), $G$. austriacum $-4 x$ is closer to the mountain than to the foothill populations of $G$. austriacum- $2 x$.

Genotype frequencies in $G$. austriacum- $4 x$ (table 5) prove an autopolyploid behaviour and tetrasomic inheritance. This is remarkable because meiotic pairing in PMC's is nearly exclusively in bivalents (Ehrendorfer 1949). Thus, with chromosome pairing evidently by chance among homologues of the four genomes, particular mechanisms strongly limiting multivalent formation have to be postulated. This situation corresponds well with observations on the auto- $6 x$ Coreopsis grandiflora var. longipes (Crawford and Smith, 1984) and on the auto-4x Tolmiea menziesii (Soltis and Riesenberg, 1986), both with freely segregating allozyme alleles in spite of "normal" meiotic behaviour. In auto-4x Dactylis glomerata Lumaret $(1981,1982)$ has shown the effect of genetic control of bivalent versus tetravalent formation on the tetrasomic inheritance of $A c p h-1$, $P x-1$ and $M d h-1$ alleles. In contrast, the recently established North American allo- $4 x$ hybrids Tragopogon porrifolius $\times T$. dubius and $T$. dubius $\times$ T. pratensis (Roose and Gottlieb, 1976) or the world-wide $4 x$ weed Capsella bursa-pastoris (Hurka et al., 1989) are obvious allopolyploids with a high proportion of fixed heterozygosity and disomic inheritance.

Generally, the increase of genotypic variation and heterozygosity from $2 x$ to $4 x$ and $8 x$ of $G$. pusillum agg. can be clearly documented from the allozyme data presented (fig. 3, table 5). There is evidence for somewhat reduced activities of multiple copies of enzyme loci in polyploids, but no suggestion of their complete "silencing". These data are in line with theoretical and factual evidence from several polyploid complexes (both auto- as well as allopolyploid) studied in a comparable way (Barber, 1970; Bingham, 1980; Lumaret, 1984).

As a consequence, polyploids are thought to exhibit a greater enzymatic diversity, more biochemical versatility, better buffering against stress factors, and broader metabolic amplitudes. This, in turn, often results in better adaptability, wider ecological niches, and successful colonization of a greater range of different habitats in polyploids. Populations of Galium austriacum- $2 x$ are rather uniform and stenoecious, those of G. pumilum- $8 x$ very variable, differentiated and euryoecious (Ehrendorfer, 1953). Similarly Festuca microstachys-6x has highly polymorphic enzyme genes and occupies a wide range of habitats (Adams and Allard, 1977). 
Galium austriacum- $4 x$ has differentiated from G. austriacum $-2 x$ and successfully expanded into the more strongly glaciation effected Lower Austrian Alps. A comparable situation has been very well documented by enzyme analyses for Dactylis glomerata- $2 x$ and $-4 x$ populations in the northwestern Iberian Peninsula (Lumaret et al., 1987; Lumaret and Barrientos, 1990) or for Tolmiea menziesii- $2 x$ and $-4 x$ in western North America (Soltis and Riesenberg, 1986). The role of polyploidy thus is to contribute to both stability and change in evolution (Ehrendorfer, 1980, 1988).

Acknowledgements We thank Dr Gerhard Beck for technical assistance and $\mathrm{Mr}$ Peter Lassnig for help in graphical matters. Our research was supported by the Austrian Research Council (FWF), project P 6189 B.

\section{REFERENCES}

ADAMS, w. T. AND ALLARD, R. W. 1977. Effect of polyploidy on phosphoglucose isomerase diversity in Festuca microstachys. Proc. natl Acad. Sci. USA, 74, 1652-1656.

AYAlA, F. J., POWEll, J. R., TRACEY, M. L., MOURAO, C. A. AND PEREZ-SALAS, S. 1972. Enzyme variability in the $D$. willistoni group. IV. Genic variation in natural populations of D. willistoni. Genetics, 70, 113-139.

BABBEL, G. R. AND SELANDER, R. K. 1974. Genetic variability in edaphically restricted and widespread plant species. Evolution, 28, 619-630.

BARBER, H. N. 1970. Hybridization and the evolution of plants. Taxon, 19, 154-160.

BINGHAM, E. T. 1980. Maximizing heterozygosity in autopolyploids. In Lewis, W. H. (ed.) Polyploidy-Biological Relevance, Plenum Press, New York, pp. 471-489.

CAVALli-MOLINA, S., MOTTA, E. P. V., SCHIENGOLD, M. AND WINGE, H. 1989. Identical isoenzyme patterns in sib plants of Relbunium hypocarpium (Rubiaceae). Rev. Brasil. Genet., 12, 361-368.

CRAWFORD, D. J. 1985. Electrophoretic data and plant speciation. Syst. Bot., 10, 405-416.

CRAWFORD, D. J. AND BAYER, R. J. 1981. Allozyme divergence in Coreopsis cyclocarpa (Compositae). Syst. Bot., 6, 373379.

CRAWFORD, D. J. AND SMITH, E. B. 1984. Allozyme divergence and intraspecific variation in Coreopsis grandiflora (Compositae). Syst. Bot., 9, 219-225.

DAVIS, B. 1964. Disc electrophoresis. II. Method and application to human serum proteins. Ann N.Y. Acad. Sci., 121, 404-427.

EHRENDoRfer, F. 1949. Zur Phylogenie der Gattung Galium. I. Polyploidie und geographisch-ökologische Einheiten in der Gruppe des Galium pumilum Murray (Sect. Leptogalium Lange) im österreichischen Alpenraum. Österr. Bot. Z., 96, 109-138.

EHRENDORFER, F. 1953. Ökologisch-geographische MikroDifferenzierung einer Population von Galium pumilum Murray (Sect. Leptogalium Lange). (Zur Phylogenie der Gattung Galium. III.) Österr. Bot. Z., 100, 670-638.

EHRENDORFER, F. 1962. Cytotaxonomische Beiträge zur Genese der Mitteleuropäischen Flora und Vegetation. Ber. Deutsch. Bot. Ges., 75, 137-152.
EHRENDORFER, F. 1980. Polyploidy and distribution. In Lewis, W. H. (ed.) Polyploidy-Biological Relevance, Plenum Press, New York, pp. 45-60.

EHRENDORFER, F. 1988. Stability versus change, or how to explain evolution. In Greuter, W. and Zimmer, B. (eds) Proc. XIV.-Inst. Bot. Congr., Berlin 1987, Koeltz, BRD, Königstein, pp. 317-333.

GOTTLIE B, L. D. 1975. Allelic diversity in the outcrossing annual plant Stephanomeria exigua ssp. carotifera (Compositae). Evolution 29, 213-225.

GOTTLIEB, L. D. 1977. Electrophoretic evidence and plant systematics. Ann. Missouri Bot. Gard., 64, 161-180.

GOTTLiEB, L. D. 1981. Electrophoretic evidence and plant populations. Progress Phytochem., 7, 1-46.

HAMRICK, J. L. 1987. Gene flow and distribution of genetic variation in plant populations. In Urbanska, K. M. (ed.) Differentiation Patterns in Higher Plants, Academic Press, London, pp. 53-67.

HARRIS, H. AND HOPKINSON, D. A. 1976. Hand book of Enzyme Electrophoresis in Human Genetics. North-Holland Publ. Comp., Amsterdam.

HEDRICK, P. W. 1971. A new approach to measuring genetic similarity. Evolution, 25, 276-280.

HURḰA, H. 1980. Enzymes as a taxonomic tool: a botanist's view. In Bisby, F. A., Vaughan, T. A. and Wright, C. A. (eds) Chemosystematics: Principles and Practice, Academic Press, London and New York, pp. 103-121.

HURKA, H., FREUNDNER, ST., BROWN, A. H. D. AND PLANTHOLT, U. 1989. Aspartate aminotransferase isozymes in the genus Capsella (Brassicaceae): Subcellular location, gene duplication, and polymorphism. Biochem. Gen., 27, 77-90.

LEVIN, D. A. 1978. Genetic variation in annual Phlox: selfcompatible versus self-incompatible species. Evolution, 32, 245-263.

LOVELESS, M. D. AND HAMRICK, J. L. 1984. Ecological determinants of genetic structure in plant populations. $A$. Rev. Ecol. Syst., 15, 65-95.

LOWREY, T. K. AND CRAWFORD, D. J. 1985. Allozyme divergence and evolution in Tetramolopium (Compositae: Astereae) on the Hawaiian Islands. Syst. Bot. 10, 64-72.

LUMARET, R. 1981. Etude de l'hérédité de phosphatases acides chez le Dactyle (Dactylis glomerata L.) diploïde et tétraploïde. Can. J. Genet. Cytol., 23, 513-353.

LUMARET, R. 1982. Protein variation in diploid and tetraploid orchard grass (Dactylis glomerata L.): formal genetics and population polymorphism of peroxidases and malate dehydrogenases. Genetica, 57, 207-215.

LUMARET, R. 1984. The role of polyploidy in the adaptive significance of polymorphism at the Got 1 locus in the Lactylis glomerata complex. Heredity, 52, 153-169.

LUMARET, R. AND BARRIENTOS, E. 1990. Phylogenetic relationships and gene flow between sympatric diploid and tetraploid plants of Dactylis glomerata L. Pl. Syst. Evol, 169, 81-96.

LUMARET, R., GUILLERM, J. L., DELAY, J., AIT LHAJ LOUTFI, A., IZCO, J. AND JAY, M. 1987. Polyploidy and habitat differentiation in Dactylis glomerata L. from Galicia (Spain). Oecologia, 73, 436-446.

MANOS, P. S. AND FAIRBROTHERS D. E. 1987. Allozyme variation in populations of six northeastern American red oaks (Fagaceae: Quercus subg. Erythrobalanus). Syst. Bot., 12 365-373.

NEI, M. 1972. Genetic distance between populations. Am. Nat., 106, 283-292.

Roose, M. L. AND GotTlieb, L. D. 1976. Genetic and biochemical consequences of polyploidy in Tragopogon. Evolution, 30, 817-830. 
SANCHEZ DE LA HOZ P. AND FOMINAYA, A. 1989. Studies of isozymes in oat species. Theor. appl. Genet., 77, 735-741. SCHWAEGERLE, K. W., GARBUTT, K. AND BAZZAZ, F. A. 1986. Differentiation among nire populations of Phlox. I. Electrophoretic and quantitative variation. Evolution, 40, 506517.

SNEATH, P. H. A. AND SOKAL, R. R. 1973. Numerical Taxonomy. Freeman, San Francisco.
SOLTIS, D. E. AND RIESENBERG, L. H. 1986. Autopolyploidy in Tolmiea menziesii (Saxifragaceae): Genetic insights from enzyme electrophoresis. Am. J. Bot., 73, 310-318.

WERTH, C. R., GUTTMAN, S. I. AND HARDY ESHBAUGH, w. 1985. Electrophoretic evidence of reticulate evolution in the Appalachian Asplenium complex. Syst. Bot., 10, 184-192. 